\title{
A PRÁTICA DA LEITURA, O EXEMPLO E A EDUCAÇÃO MORAL NA ESCOLA PRIMÁRIA
}

\author{
FRANCISCO ARI ANDRADE \\ Universidade Federal do Ceará (UFC), Ceará, Fortaleza, Brasil
}

\begin{abstract}
Resumo: O presente artigo destaca uma prática de leitura, proposta pela professora primária Ana Facó (1855-1926), na cidade de Fortaleza, no começo do século XX. O objetivo do estudo é demonstrar a aplicação do método intuitivo na sala de aula, por meio da leitura de um conto, no qual o exemplo apresentado visava à educação moral dos alunos. Nos aspectos metodológicos, o estudo utilizou o jornal como fonte. Na hemeroteca da biblioteca pública estadual, no setor de microfilmagem, foi localizada uma série de nove contos publicada na coluna "Escola", intitulada "Minha palmatória para crianças", em edições diferentes do Jornal do Ceará, no período de maio a junho de 1907. Embora conservador, porque previa o controle das crianças e a manutenção da ordem social, tal estudo é relevante pela influência da pedagogia de J. H. Pestalozzi (1746-1827) na questão da educação moral na escola primária.
\end{abstract}

Palavras-chave: Educação moral. Método intuitivo. Exemplo. Prática de leitura

\section{INTRODUÇÃO}

O presente artigo vislumbra uma prática de leitura na escola primária, empreendida por uma professora, na cidade de Fortaleza, chamada Ana Facó (1855-1926), no começo do século XX. Valendo-se do método intuitivo, a partir da leitura de um conto, previamente escrito por ela e publicado num jornal local, levava os alunos a tomarem o enredo como exemplo', visando à 
educação moral deles. Sob influência do educador J. H. Pestalozzi (1746-1827), aquela prática de leitura de contos previa o futuro da sociedade, a partir dos cuidados morais com a infância, na escola primária.

Como professora e beletrista, movida pela escassez de material didático, a mestra publicou uma série de pequenos contos voltados para o público escolar, em jornal de circulação na cidade.

A educação moral, entendida como uma prerrogativa da pedagogia moderna, sedimentada nas matrizes do pensamento de J.H. Pestalozzi (17461827), fez eco na educação brasileira, a partir da segunda metade do século XIX.

O desenvolvimento deste estudo foi possível graças à localização de alguns exemplares do Jornal do Ceará, microfilmados e catalogados no setor hemeroteca da biblioteca pública estadual, onde foi possível a identificação dos contos na coluna "Escola" e da seção "Minha palmatória - para crianças", com um total de nove contos de autoria da referida professora, publicados nos meses de maio a junho de 1907.

Admite-se que tal experiência de leitura, embora conservadora, porque previa a disciplina do indivíduo à ordem social estabelecida, do ponto de vista pedagógico tenha sido inovadora, com a aplicação do método intuitivo na sala de aula.

\section{A EDUCAÇÃo MORAL E A PEDAGOGIA MODERNA}

Pelo exemplo se educa, moralmente, a criança. Eis uma máxima encontrada nas páginas de um dos tratados de educação desenvolvidos pelo "pedagogista" Johann Heinrich Pestalozzi (1746-1827), no século XIX (HOUSSAYE, 2013).

Como pensador e educador, as ideias do mestre de Burgdorf influíram no pensamento educacional brasileiro no século XIX e início do século XX. A maioria dos nossos políticos e intelectuais, que estiveram às voltas com o debate político em torno das garantias republicanas da educação primária, foi influenciada pelo pensamento pestaloziano.

É possível a identificação de tal influência nas reformas educacionais da segunda metade do século XIX. Mas o legado da maior influência, segundo conta, foi o pensamento de Abílio Cesar Borges (1924-1891), o Barão de Macaúbas, por meio de dois estudos: o Relatório de 1856 e a tese apresentada no Congresso Pedagógico Internacional de Buenos Aires, de 1882. "Era a pedagogia moderna procurando pôr em prática e difundir no Brasil os 'métodos novos' de ensino" (SAVIANI, 2008 p.155).

No século XIX, segundo Luzuriaga (1976, p.181), a educação ganhava importância no debate político e acadêmico, intimamente ligada 
aos acontecimentos da Revolução Industrial e das revoluções políticas em evidência nas nações europeias. A concentração de grandes massas de populações nas principais cidades europeias reforçava o interesse político e social de cuidar da educação e efetivar a escola primária do ponto de vista nacional. Travava-se uma luta em defesa da educação, vista no rol das questões nacionais por partidos políticos, conservadores, liberais, reacionários, progressistas, religiosos e liberais. Daquele século em diante, segundo o autor, procederam os sistemas nacionais de ensino e as grandes leis da instrução pública emanadas dos grandes centros europeus e norteamericanos. A educação universal, gratuita, obrigatória e, em algumas situações, leiga ganhou notoriedade pública. A educação primária e as escolas normais, voltadas para a preparação do magistério, constituiriam os dois novos elementos favoráveis à consolidação da educação do "soberano".

Nesse contexto, se destacaria a figura de J.H. Pestalozzi, assentando as bases da educação primária moderna. Em defesa da instrução de crianças pobres, mesmo que movido por filantropia, antecipa a escola de base popular (LARROYO, 1974). Das sugestões apresentadas por Rousseau (1712-1778) acerca da educação, Pestalozzi teria desenvolvido sua teoria de educação moral (HUBERT, 1957).

A educação moral em Pestalozzi, no contexto do século XIX, passou a ser a missão da pedagogia moderna. Por meio dela, a convicção da elevação espiritual dos alunos, cujas representações e noções acerca do direito e do dever, no universo psicossocial da criança, seriam suficientes para a condução do indivíduo à condição de sujeito moral, no mundo civilizado (HOUSSAYE, 2013). Como defendia Pestalozzi "el hombre moral es la fusión del intuitivo e del racional" (FERRIÈRE, 1928, p.34).

Seguindo a tradição, Pestalozzi também enxergava a infância como uma fase negativa da vida. A condução para o bom caminho passaria a depender da ação docente. Pairava a convicção de a educação ser capaz de levar a criança a uma vida ativa e útil.

Ao dissertar sobre a educação moral, Pestalozzi argumenta haver no ser humano uma força autônoma capaz de representar o indivíduo a si mesmo a todas as coisas do mundo. Como um imperativo na nossa própria natureza, tal força seria a autonomia e se localiza, segundo ele, numa fronteira tênue entre a existência animal, a existência social e a existência moral.

"Ela é o que sou, e eu sou o que ela é" (HOUSSAYE, 2013, p.37). Assim, começaria sua exposição acerca da educação moral. Para chegar a tal entendimento, parte das três idades do homem. Nesse anúncio, as etapas da humanidade se dividiam em fase infantil, juvenil e adulta. Esses três estados 
estariam classificados entre estado natural, estado social e estado moral, referindo-se a cada uma das fases do desenvolvimento humano.

Ao dar ênfase ao entendimento do estado natural, associado à infância, Pestalozzi argumenta tratar-se da condição do "gozo sensível". Enquanto criança, sua condição fica aproximada à inocência animal e, por isso, com conexões à animalidade. Em tal condição, o indivíduo assume uma atitude egocêntrica, podendo se perder entre o prazer e a dor. No estado natural, há total ausência das duas maneiras de o indivíduo enxergar as coisas do mundo: a autonomia e o direito. A ignorância peculiar a tal estado leva a fusão dessas duas forças ao campo da ilusão, prevalecendo a aparência como verdade.

O desafio da educação moral é levar a criança à fase adulta, na condição de ser moral, com os conhecimentos fundamentais acerca do direito e do dever adquiridos no processo escolar primário. No estado de aprendiz, o indivíduo ia perdendo sua liberdade natural, tornando-se, com a educação moral, uma criatura do acordo e do contrato. Tal processo se daria na relação do discípulo com o mestre. O pai colaborava transferindo ao mestre o direito de educar o filho. Ao mestre, por sua vez, cabia o dever de educação da criança, na esperança do futuro, pautado na verdade e na confiança (HOUSSAYE, 2013).

\section{A EDUCAÇÃO MORAL E A PEDAGOGIA MODERNA NO BRASIL}

A influência da pedagogia moderna e da educação moral no Brasil remonta à segunda metade do século XIX. Conforme anteriormente apontado por Saviani (2008), a influência pestalozziana era percebida nos debates políticos, nos movimentos educacionais e nas reformas de instrução pública anunciadas na segunda metade do século XIX e nas primeiras décadas do século $\mathrm{XX}$.

A instrução primária, e com ela a defesa da educação moral das crianças, passava pela orientação da pedagogia moderna. Se as sociedades industriais apresentavam o modelo da escola moderna como uma nova ordem política, os setores sociais engajados passaram a exigir uma nova orientação moral das crianças a partir da educação primária, orientada pelos valores das sociedades industriais.

Com relação à educação moral no Brasil, Saviani (2008) reforça a presença do Barão de Macaúbas no Congresso Pedagógico Internacional de Bueno Aires, em 1882, apresentando sua tese, dividida em duas seções. $\mathrm{Na}$ primeira, teria feito uma abordagem e uma reflexão acerca da formação dos mestres de ensino, propondo a necessidade de criação das escolas normais internas, onde os mestres de ensino primário fossem formados sem as influências do meio. Na segunda seção de sua fala, ressaltaria a necessidade 
de a escola primária sustentar a disciplina e manter mecanismos que favorecessem nos educandos o gosto pela instrução, sendo recomendada a abolição do uso de castigos correcionais e de premiações aos que se destacassem nos estudos.

Do ponto de vista da educação moral, havia uma íntima ligação com a dimensão religiosa. Associava como pressuposto da educação moral o contato dos alunos com exemplos vivos, criticando a tradição da escola arraigada na exortação e na prática da memorização de regras morais. Segundo seus axiomas, somente por via da educação moral, "a escola primária iria realizar a reforma dos costumes e preparar os jovens de ambos os sexos para a vida pública assim como para desempenhar os deveres de pais e mães de família" (SAVIANI, 2008, p.15).

As reformas de instrução escolar que se sucederam por todo o século XIX e as primeiras décadas do século XX no Brasil, embora voltadas para as escolas da capital do governo central, tiveram uma orientação pedagógica moderna, numa tentativa de educação moral na educação primária.

\section{Escola Normal, os grupos escolares e a Pedagogia moderna no Limiar REPUBLICANO}

Como modelo de escola moderna e republicana, seguindo o novo modelo da escola pública da cidade de São Paulo, primeira cidade brasileira a implantar um grupo escolar, a maioria das capitais brasileiras passou a instituir uma escola graduada (MARCILIO, 2005).

Dentro de uma nova dimensão educacional e pedagógica, aquelas unidades de ensino público graduado deveriam simbolizar um modelo de modernização pedagógica, condizente com as matrizes da filosofia educacional advindas da Europa e dos Estados Unidos, a partir da segunda metade do século XIX (SOUSA, 2008).

A implantação de grupos escolares consolidaria a pedagogia moderna no Brasil. A Reforma Leôncio de Carvalho, de 1879, havia recomendado o método de lição das coisas e a educação moral nas escolas primárias, embora restritos ao município da corte, reflexo da influência do pensamento educacional internacional advindo dos grandes centros internacionais. No entanto, a agenda da política educacional republicana giraria em torno da questão da reforma do ensino primário, ao incluir a necessidade da organização curricular, mas mantendo o método de ensino intuitivo.

A instituição dos grupos escolares no Brasil não correspondeu a um projeto nacional de educação. Presa à legislação vigente, a iniciativa partiu 
dos governos estaduais. Inspirando-se nos modelos internacionais de escolas graduadas, a experiência paulista serviu de esteio ao projeto republicano e de modelo para as demais unidades federativas empreenderem suas reformas de organização do ensino primário (SAVIANI, 2008).

Por meio do modelo de escolas graduadas, apostava-se numa nova orientação pedagógica e política da escola primária (ROSA, 2008), com a introdução do método de ensino intuitivo (VALDEMARIM, 2004), em substituição ao método de ensino mútuo.

Os grupos escolares e a Escola Normal locupletavam a pedagogia moderna no início do século XX, no Brasil. Ambos completariam o ciclo da formação moderna atribuída a partir da educação primária. As capitais da República contariam, além de uma unidade de ensino para formação de professoras primárias, também com as escolas normais e com os grupos escolares modelos.

A Escola Normal do Ceará foi inaugurada na cidade de Fortaleza em março de 1884 (CASTELO, 1970). Na ocasião da matrícula de Ana Facó como normalista naquela instituição de ensino, encontrava-se sob a organização do professor José de Barcelos, considerado o pioneiro da pedagogia moderna no Ceará. Nomeado para ministrar a disciplina Pedagogia e Metodologia, considerada a principal do currículo de formação das professoras primárias, deduz-se que o lente José de Barcelos tenha sido o responsável pela introdução do pensamento de Pestalozzi na Escola Normal do Ceará.

Como atuante no cenário das letras, em várias ocasiões fora ouvido em conferências, nas tertúlias literárias e científicas da cidade, falando sobre pedagogia. Integrando um movimento estético e científico no Ceará chamado de Clube Literário, em 1887, em parceria com escritores que se destacariam no cenário da literatura nacional como Oliveira Paiva, Antonio Bezerra, José Olímpio, Farias Brito, dentre outros, José de Barcelos seria idealizador da revista $A$ Quinzena, em cujas páginas, além da crítica literária, da poesia, da prosa e da filosofia eclética, circulariam, também, textos de cunho científico. Num de seus números, há registro de um ensaio de sua autoria sobre a obra e o pensamento de Pestalozzi (BARREIRA, 1948). Além de Pestalozzi, cabe ressaltar outro pensador apropriado por ele e posto em voga na formação das normalistas cearenses. Tratava-se do norte-americano Norman Calkin, autor do livro $A$ lição das coisas, traduzido pelo ministro Rui Barbosa (1849-1923).

No tocante ao método da escola ativa, influência direta da proposta pedagógica de Pestalozzi e de Calkins, é possível a identificação de imagens literárias extraídas do romance $A$ normalista, do escritor cearense Adolfo Caminha (1867-1897). Publicado em 1893, considerado um romance polêmico 
para a época, porque se chocava com o pensamento moralizador da elite local, há uma descrição do ambiente interno da escola, numa demonstração da orientação científica, própria da pedagogia moderna, necessária à formação das normalistas:

O edifício da Escola Normal, a um canto do quadrilátero, pintadinho de fresco, cinzento, com as janelas abertas à claridade forte do dia, tinha o aspecto alegre d'uma casa de noivos acabada de criar-se. [...] Raparigas de todos os tamanhos, trajando branco, azul e rosa conversavam animadas de livro na mão, formando grupos, rindo, ao vestíbulo que separava a sala de música do gabinete de ciência naturais, no pavimento superior (CAMINHA, 2007, p.69).

Se o recorte acima dá conta do discurso educacional que orientava cientificamente a formação pedagógica na Escola Normal, também demostrava uma contradição entre a teoria e a prática:

A sala era bastante larga para comportar outras tantas discípulas, com janelas para a rua e para os terrenos devolutos, muito ventilada. Era ali que funcionavam as aulas de ciência físicas e naturais, em horas diferentes das de geografia. Não se via um só mapa, uma só carta geográfica nas paredes, onde punham sombras escuras de peles de animais selvagens colocadas por cima de vidraças que guardavam intactos, aparelhos de química e física, redomas de vidro bojudas e reluzentes, velhas máquinas pneumáticas nunca servidas, pilhas elétricas de Bunsen, incompletas, sem amálgamas de zinco, os condutores pendentes num abandono glacial; coleções de minerais, numerados, em caixinha, no fundo da sala, em prateleiras volantes...Nenhum indicio, porém, de esfera terrestre (CAMINHA, 2007, p.71).

No entanto, apesar das contradições, por via da disciplina Pedagogia e Metodologia, o professor Barcelos procuraria aproximar as normalistas da pedagogia moderna. Prova disso, anos depois, no exercício da docência na escola primária, a professora Ana Facó ia desenvolver a prática de leitura entre as crianças do grupo escolar, visando à educação moral, por meio do uso da orientação do método intuitivo.

\section{A professora Ana Facó: a MULher, SEU tempo e a PEDAgogIa MOdeRnA}

Nasceu Ana Facó em Beberibe, na época pertencente à comarca de Cascavel, a 80 km de Fortaleza, litoral leste, em 10 de abril de 1855. Faleceu em Fortaleza, a 22 de junho de 1926. Segundo contam, quando o professor paulista Manuel B. Lourenço Filho (1897-1970) esteve aqui, a serviço do governo, para empreender a reforma do ensino primário do 
Ceará, teria Ihe rendido reverência pelo trabalho pedagógico dedicado às crianças da escola local.

Muito comum, em épocas anteriores, as crianças chegavam alfabetizadas à escola primária. Com a menina Ana Facó não foi diferente. Chegou à escola de primeiras letras, regida pela mestra de ensino chamada Maria Carolina Pereira Ibiapina, na comarca de Cascavel, alfabetizada. Seu preceptor das primeiras letras fora o irmão mais velho, José Baltasar.

Ingressou como aluna na Escola Normal da cidade de Fortaleza um ano após a criação da referida instituição. Sairia diplomada normalista em 1886. Mas, ao contrário das expectativas familiares, o casamento não era seu projeto de vida. O magistério e a literatura sim e representaram o caminho escolhido para sua liberdade. O magistério foi abraçado na esperança de prover as necessidades financeiras, mas os anos de trabalho transformaram a educação num ideal de vida. Revelara-se uma exímia pedagoga e filantrópica, discípula de Pestalozzi no zelo com o ensino e no amor dedicado às crianças. Criou material didático. Escreveu histórias para as crianças. Compôs hinos para serem cantados nas escolas públicas, além de ter desenvolvido o método de alfabetizar crianças pelo jornal (ANDRADE; LOBATO, 2013).

Apesar de agnóstica, pois a influência da filosofia cartesiana² 2 a toldaria à fé católica, não era cética nem desiludida com a existência. Pelo contrário, acreditava e nutria esperança num futuro melhor para as crianças, por meio da educação e da formação moral.

\section{A prática da leitura em SAla de aula dos Contos da COluna "Minha PALMATÓRIA - PARA AS CRIANÇAS" E A EDUCAÇÃO MORAL}

A educação moral coaduna com o método intuitivo, também conhecido como Método da Lição das Coisas, próprio para um modelo de escola ativa. O método intuitivo vai representar no século XIX uma tentativa de renovação pedagógica da escola primária. Seus defensores comporão uma corrente vigorosa em defesa da educação moderna, por meio de um novo método de ensino capaz de educar pelos sentidos, pelas coisas e pela experiência. O método parte da premissa de incitar nos alunos o uso dos sentidos para a intuição intelectual, na aquisição do conhecimento (VALDEMARIN, 2004).

Esse método introduz um novo elemento no processo de educação primária das crianças. Trata-se do material didático. Os materiais didáticos na sala de aula representariam para o ensino intuitivo o que os fenômenos e as leis da natureza representam para a ciência empírica. Admitia-se que o 
conhecimento proveniente dos sentidos devia ser exercido sobre os objetos ao redor do aluno (VALDEMARIN, 2004).

O ciclo da educação moral avançaria por graus. Um pequeno esboço de como funcionaria a educação moral, por via do método intuitivo, pode ser assim apreciado. O primeiro contato da criança com a realidade objetiva se daria em um ambiente organizado moralmente. Em tal ambiente, em contato com o objeto, desenvolvia-se o grau intuitivo da educação moral, uma vez que o mestre de ensino seria capaz de apresentar o exemplo ao aprendiz. $O$ exemplo, por sua vez, constituía-se no "alimento ético" da educação moral. O grau intuitivo se daria na prática do fazer. Pela apropriação intuitiva do exemplo, o aprendiz seria remetido à etapa da compreensão racional, passando do sentido para a intuição intelectual, a agir de boa vontade e com autonomia (LARROYO, 1974).

A proposta acima descrita parece ter sido levada em consideração na prática de leitura aplicada pela professora Ana Facó aos seus alunos no grupo escolar. Pelo viés da literatura, o gênero conto traria a mensagem necessária à intuição dos alunos. Cada conto lido em sala de aula era tomado como modelo ético, capaz de instruir nos escolares o bom senso da educação moral, visando agirem com autonomia na vida adulta.

Para dar conta do seu intento de educação moral das crianças, Ana Facó se debruçou a escrever e a publicar pequenos contos no jornal, com a finalidade de desenvolver valores morais no convívio em sociedade dos alunos de idade escolar entre cinco e nove anos.

Nos contos analisados neste estudo, é possível refletir sobre alguns princípios morais que estimulavam os pequeninos a aplicá-los na vida prática. Os textos se encontram escritos numa linguagem simples, delicada, instigadora e curta. Habilidosa no mundo da estética e das letras, usando poucas palavras e linhas, a mestra de ensino conseguiu tratar de muitos assuntos polêmicos, inerentes à vida moderna em evidência, adequando a discussão e a recomendação ética ao universo cognitivo da faixa etária infantil, em poucas palavras no curto espaço do quadrante da página do jornal.

Ao se analisar cada um dos contos, tomou-se a liberdade de abstrair o exemplo de cada um. Ao se trazer uma síntese de cada um daqueles contos, verifica-se o que está proposto: o exemplo na moral de cada historinha, para sensibilizar as crianças.

No primeiro conto analisado, intitulado "Julinha", o exemplo é não julgar ninguém pela aparência. As aparências, segundo o conto, nos levam ao engano. $O$ texto começa indicando o horário em que se iniciavam as aulas na escola pública da cidade, às 10 horas do dia. No conto, a professora 
entendia que aquele grupo composto de crianças de cinco a nove anos fora a ela confiado. Pela característica, era uma classe de ensino mútuo. Ao adentar na sala de aula, deparara-se com alunos atônitos, porque inseridos num "mundozinho" desconhecido por eles. Depois de cumprimentá-los, percorrera com a vista o grupo e fora percebendo os semblantes individuais de cada um. A maioria vigorosa, vestida decentemente, se apresentava sorridente. Mas, dentre eles, alguns chorosos e outros carrancudos. No meio do percurso ocular, estacionaria o olhar sobre uma aluna "risonha pequerrucha", de cinco anos. Viera a perguntar como se chamava. Prontamente, a resposta: "Julinha". Em seguida, outra pergunta: “De quem era filha?”. E a resposta em seguida: "Do papai". A professora riu da cena e a beijou na face. No entanto, consigo mesmo, imaginou que aquela criaturinha ainda ia levar um tempo para se habituar à vida escolar. Ledo engano. Depois de alguns meses, Julinha se destacava dentre as alunas de maior rendimento nos estudos. A priori, frustrara-se no seu diagnóstico aparente. Julinha não era o que aparentava à mestra no primeiro dia de aula.

No segundo conto, "Zuza", o exemplo é: aquele que enxerga o cisco no olho do vizinho esquece de enxergar no seu. O texto se inicia apresentando o cenário em um dia de festejos populares na cidade. Uma tarde de domingo de sol rubro no ocidente, preste a se pôr. Ao descrever que no céu límpido não se viam nuvens, o conto aguça nos alunos dois conceitos básicos da geografia que se referem à classificação das nuvens: nimbo e cirrus. Mas o texto segue, apresentando o Zuza, louro e travesso. Naquele dia de festa, era mais um menino a correr sem direção, atraído pelos fogos de artifícios. Carregava em cada uma das mãos um rojão, que pretendia soltar. Ao avistar um grupo de meninos concentrados em torno de algo, fora movido pela curiosidade de se dirigir até a turma. Os meninos compravam alfinins. Diante do tabuleiro do vendedor, Zuza manifestou o desejo de comprar aquela iguaria. Porém, antes da compra, resolvera manifestar escrúpulo de asseio e quisera saber se o ambulante estava com as mãos asseadas. O vendedor retrucou dizendo que as suas é que se encontravam sujas, com unhas crescidas e com as palmas das mãos enegrecidas de cinzas. O riso dos colegas o fez sair dali envergonhado, em veloz correria em direção à sua casa. Segundo a história, o menino vira o argueiro no olho do vizinho, mas não percebera que havia, também, nos seus.

No conto "O choramingas", terceiro da série, o exemplo abstraído é: o medo ensina a temer. $O$ personagem é um aluno por nome de João. Os colegas o chamavam de Janjão. Um menino mimado que chorava por qualquer coisa. Detestava os livros e, quando o obrigavam a ir à escola, ia sempre chorando. Devido a essa característica de ser chorão, coube-lhe o apelido de "choramingas". Um dia, a caminho da escola, sempre a chorar pelo 
caminho, deparara-se com um velhinho sentado em uma calçada, a desfrutar da sombra do dia. Para que se livrasse do choro, presenteou-o com três goiabas. Pediu que se sentasse um pouco e que lhe contaria uma história. A história falava de um rei bondoso por nome de Luís. Numa certa manhã, ao passear pelo bosque, uma plantinha verde-gaio chamou a atenção de sua majestade. Imediatamente, quebrou um galho da planta. Logo começou a brotar uma corrente de seiva, que fez o rei se assombrar. Em seguida, uma voz o amaldiçoava, afirmando que teria um filho cujos olhos nunca secariam, teria horror aos livros e as orelhas crescidas, ao ponto de não poder usar chapéu. O menino levantou-se resignado, dizendo que aquela história era sem graça. $O$ velho ainda teve tempo de perguntar, antes que sumisse na poeira da rua, se por acaso ele não era o filho do rei. Daí em diante, Janjão, na sala de aula, passaria a controlar o choro e, de vez em quando, apalpava as orelhas, temendo que estas estivessem crescendo.

O conto "Escolha de flores" é o quarto da série analisado. O exemplo destacado é: o amor da mãe pelos filhos e vice-versa. Os personagens são uma mãe e seus três filhos: um de sete, outro de seis e outro de quatro anos. A genitora chamava-se Dona Eugênia. Naquela manhã, se entretinha com as crianças em primorosa educação doméstica. Na ocasião, alerta aos filhos que naquele dia era seu aniversário. Chamou o filho mais velho e pediu que fosse até o jardim e escolhesse uma flor para presenteá-la. Depois de alguns minutos, o menino Tito voltava, trazendo uma rosa na mão. A mãe o indaga: "Uma rosa, filho?"E ele retruca: "Sim, mamãe. Você é a mais bonita das rosas". Em seguida, solicita à filha de seis anos que faça o mesmo. Momentos depois, voltava Nina, trazendo-Ihe um ramo de sempre-viva. Entregou-lhe, dizendo que sempre-viva não morre. E, por isso, a mãe nunca morreria. Finalmente, chegou a vez do menino de cinco anos. Minutos depois, Nilo voltava trazendo na fralda da camisa um amontoado de flores de todos os tipos que encontrara no jardim. A justificativa dada fora que não achara nenhuma flor à altura da sua mamãe. Por isso, resolvera trazer todas que encontrara. $\mathrm{O}$ amor entre pais e filhos era recíproco.

No quinto conto, intitulado "Dedicação fraterna", o exemplo trazido diz respeito ao amor entre duas irmãs, que é capaz de salvar vidas. As personagens são Déa e Cloressi. Duas irmãs que se amam. Por ser mais velha, Cloressi cuida de Dea, que tem uma saúde debilitada. Num dos passeios matinais, receitado pelo médico, Cloressi percebera o clima chuvoso que se formava no firmamento. Preocupada com a saúde debilitada da irmã, entrara em desespero, por não encontrar abrigo seguro onde pudessem se abrigar da chuva. Temendo serem pegas pelo temporal, antes de chegar em casa, tomou a inciativa de sacar a saia branca que estava por debaixo do vestido 
para agasalhar a irmã contra a chuva. Uma senhora que observava aquela cena a distância, ao vê-las passar diante de si, exclamaria, em ar de contentamento: "ainda bem que existem anjos da guarda na terra". Ao chegarem, com a irmã mais nova protegida da chuva, a mãe que as aguardavam, aflita, exclamou: "Fizeste a coisa certa, filha, tu tens um anjo bom". E, sem pestanejar, a filha mais velha lhe responde: "Sim, mamãe, mas meu anjo é você".

Uma apreciação é necessária ser feita em relação ao tema do conto seis: "A greve". Admite-se que o texto traga reflexos de um período em que trabalhadores se organizavam pelo Brasil, sob influência dos sindicatos de orientação anarquista. Mas não é o caso de se abrir espaço para essa discussão agora. O surpreendente de tudo é o texto ser desenrolado em torno do referido tema, como expressão de luta política.

O exemplo desse conto é o dever acima da nossa vontade. No final da aula, dois alunos se dirigem à professora e anunciam uma decisão tomada no recreio com os demais colegas. lam fazer greve. No dia seguinte, nenhum aluno daquela classe viria à escola. Surpreendida com tamanha ousadia, a professora indaga por que não pretendiam vir à aula no dia seguinte. Afirmavam ser véspera de $S$. João. Aproveitariam, então, para fazer greve, antecipando o feriado do dia. A mestre argumentara que a lgreja recomendava guardar, apenas, o dia do santo. Em seguida, procurou inquirilos se sabiam o que de fato era uma greve. Antes de dizerem alguma coisa, a professora fitou-os e foi respondendo em tom compassado que greve era o avesso do dever e o dever estava acima de tudo. Em seguida, expunha uma justificativa, almejando que os alunos mudassem de ideia. $\mathrm{O}$ ano letivo era de nove meses. Tirando-se as faltas por motivo de doenças, os domingos, as quintas-feiras e os feriados, o ano letivo se reduzia a seis meses de aula. Por isso, não os apoiaria naquela intenção. Greve não. Assim como os demais, gostava das férias. Mas não abusava delas porque tinha um juiz que lhe julgava os atos: a consciência; tinha um mentor a quem devia obediência: o regulamento; e as amáveis criaturinhas a quem Ihe fora confiada a educação eram da sua responsabilidade. Tudo aquilo, segundo a professora, chamava-se dever. E que, diante daqueles argumentos, fizessem o que Ihes conviessem, mas não contassem com seu apoio. Os meninos se entreolharam e declinaram da ideia. Despediram-se da professora dizendo-lhe um "até amanhã".

No conto sete, o modelo interpretado é: quem muito fala, pouco pensa e não pesa o que diz. Fábio tinha entre oito ou nove anos e, apesar da inteligência, era pouco estudioso. A característica peculiar de Fábio era ser taramela. Na sala de aula, falava sobre tudo. Não parava de falar. Para ele, não havia segredos. Até os assuntos domésticos eram trazidos à baila. Um dia, após 
a aula, o professor veio a conversar com ele. Dera-lhe conselhos paternais de como devia ser discreto nas questões que não diziam respeito aos outros. Ao chegar em casa, Fábio perguntara a mãe o que era um deserto. A resposta veio imediatamente, como nos manuais de geografia. Para espanto da mãe, não se convencera da resposta. Disse se tratar de um quarto escuro que havia na escola e que para lá o professor o mandaria. No dia seguinte, ao chorar por não querer ir à escola, o pai o obrigou a ir na companhia do irmão mais velho, chamado Antonio, recomendando a este que procurasse o mestre de ensino para saber o que acontecera no dia anterior, com o Fábio em sala de aula. Em reunião reservada, o professor explicou a Antonio que havia recomendado a Fábio discrição na sua fala com os demais colegas e que não fizesse dos seus conselhos uma pregação no deserto. O irmão entendeu a situação. Despediu-se do professor, balançando a cabeça, negativamente, a exclamar: "Esse Fábio!".

No conto oito, o exemplo é: o perdão é o melhor exemplo de correção. Eis o exemplo trazido pelo conto "As duas amigas". Honorina e Hugolina eram duas crianças da mesma idade. Moravam vizinhas na mesma rua. Como duas irmãs, brincavam juntas com as bonecas. No dia do aniversário de 10 anos, Honorina ganhara um aparelho de chá e duas cadeirinhas de bonecas. Ambas ficaram maravilhadas com o presente. Improvisaram um bangalô e arrumaram a casa como de gente grande. No dia seguinte, Honorina deu por falta do brinquedo. Apesar de todo o esforço, as buscas foram inúteis. Haviam sumido uma parte do aparelho e uma das cadeirinhas. Passados três dias, Honorina fez uma visita de cortesia à casa da coleguinha. Ao adentrar no recinto da sala, encontrou a amiga de costas para a entrada da casa a brincar com os seus pertences, sem se dar conta da sua presença ali. Honorina ficou desapontada com a cena que enxergara. Antes de qualquer coisa, a mãe da amiguinha aparece ao recinto e, por meio de um abraço, agradeceu o presente que a filha ganhara no dia do aniversário da amiga. Após a mãe retornar aos seus afazeres, Honorina fita a amiga e lamenta a inocência de sua mãe em acreditar naquela mentira. Esta esboça choro, reconhece o erro, faz menção de devolver os brinquedos e pede perdão pelo delito. Honorina a abraça e a perdoa, dizendo-lhe para ficar com os brinquedos. Tomando o acontecimento como lição, daquele dia em diante a amiga nunca mais veio a se apropriar do que era alheio.

Finalizando a série, o exemplo do conto nove é a desobediência gerar o castigo, por merecer. A história se inicia dando conta de uma casa no campo onde, nas proximidades, havia uma fonte em que as crianças gostavam de espiar a nascente d'água. $O$ sol estava prestes a desaparecer quando as crianças insistiam em pedir autorização da mãe para irem até lá. 
A mãe recomendara que não, pois estava perto do anoitecer. Deixassem para outro dia. Fossem brincar por perto de casa, sem se sujar, mas não fossem para o lado da fonte. Anália, a menor do grupo, resolveu se furtar ao olhar da mãe e dirigiu-se ao olho d'água. Lá chegando, debruçou-se sobre o poço, entusiasmada com as borbulhas que brotavam de dentro para fora. Os irmãos, que brincavam nas proximidades, ouviram um baque na água. Era a menina que havia caído na fonte. Por sorte, a água deu na cintura. Todos correram para lá e a encontraram encharcada. Foi motivo de zombaria. Em casa, o pai, ao tomar conhecimento do fato, disse aos filhos: "Recebemos a recompensa ou o castigo pelas nossas boas ou más ações".

Como se percebe, os modelos trazidos em cada um dos contos concentram um rol de palavras-chave que encerram a pretensão da educação moral.

\section{CONCLUSÃo}

Difícil mensurar o alcance efetivo daquela prática de leitura, como proposta de educação moral de alunos na escola primária.

Muitas iniciativas docentes, de cunho salvífico, movidas pelo sentimento de amor à causa educacional, são encontradas ao longo da construção da nossa experiência escolar. As ações individuais, nem sempre bem-vistas aos olhos de setores conservadores, padecentes pela ausência de apoio financeiro, devem ser sempre louvadas por se tratar de buscas de saídas diante dos desafios educacionais não enfrentados com eficácia pelo poder público.

Embora se entenda a prática de educação moral da professora Ana Facó como conservadora, porque previa o controle das crianças e a manutenção da ordem social, do ponto de vista pedagógico era inovadora pela aplicação do método intuitivo na sala de aula, a prever o futuro da sociedade a partir dos cuidados morais com a infância.

Aqueles contos, caprichosamente elaborados pelo senso estético de uma beletrista do início do século XX, tinham uma intenção pedagógica. Ofereciam material didático à prática da leitura e da escrita, mesmo que o sentido teleológico fosse a educação moral das crianças, visando à correta vida adulta em sociedade. 
THE PRACTICE OF READING, EXAMPLE AND MORAL EDUCATION IN PRIMARY SCHOOL

ABSTRACT: This article highlights a reading practice proposed by the primary teacher Ana Facó (1855-1926), in the city of Fortaleza, at the beginning of the 20th century. The purpose of this study is to demonstrate an application of the intuitive method in the classroom by reading a short story, where the example presented was aimed at the moral education of students. In methodological terms, the study uses the newspaper as a source. In the newspaper library of the state public library, in the microfilming sector, a series of nine stories published in the School column, titled "My Palmatoria-for children", in different editions of the Jornal do Ceará, in the period of May to June of 1907. Although conservative, because it provides for the control of children and the maintenance of social order, such study is relevant because of the influence of pedagogy of JH Pestalozzi (1746-1827) on the literature of moral education in primary school.

KEYWORDS: Moral education. Intuitive method. Example. Reading practice.

\section{LA PRÁCTICA DE LA LECTURA, EL EJEMPLOY LA EDUCACIÓN MORAL EN LA ESCUELA PRIMARIA}

RESUMEN: El presente artículo destaca una práctica de lectura, propuesta por la profesora primaria Ana Facó (1855-1926), en la ciudad de Fortaleza, a comienzos del siglo XX. El objetivo del estudio es demostrar la aplicación del método intuitivo en el aula, por medio de la lectura de un cuento, en el cual el ejemplo presentado apunta a la educación moral de los alumnos. En los aspectos metodológicos, el estudio utilizó el periódico como fuente. En el sector hemeroteca, de la biblioteca pública estatal, en el sector de microfilmación, se ubicó una serie de nueve cuentos publicada en la columna Escuela, titulada "Mi Palmatoria - para niños", en ediciones diferentes del Jornal do Ceará, en el período de mayo a junio de 1907. Aunque conservadora, porque preveía el control de los niños y el mantenimiento del orden social, tal estudio es relevante por la influencia de la pedagogía de JH Pestalozzi (1746-1827), en la cuestión de la educación moral en la escuela primaria.

Palabras clave: Educación moral. Método intuitivo. Ejemplo. Práctica de lectura.

\section{NOTAS}

10 termo exemplum, como ferramenta pedagógica de educação moral cristã, é destacado pelo historiador Jacques Le Goff $(2010$, p.81) como uma narrativa breve com a função de persuadir e disciplinar o discípulo. Sua origem remonta 
ao período da Europa medieval. Bispos e padres utilizavam exemplos nos seus sermões para a orientação moral dos catecúmenos.

2 Corrente filosófica representada pelo francês René Descartes (1596-1650).

\section{REFERÊNCIAS}

ANDRADE, F. A.; LOBATO, A. M. L. A mãe ensina, o filho aprende as lições do ABC pelo jornal. Revista HISTEDBR , Campinas, n. 54, p. 144-155, dez. 2013.

AZEVEDO, F. Os sistemas escolares. In: PEREIRA, L.; FORACCHI, M. M. Educação e sociedade. 13. ed. São Paulo: Ed. Nacional, 1987.

BARREIRA, D. História da literatura cearense. Fortaleza: Ed. do Instituto do Ceará, 1948.

CAMINHA, A. A normalista. São Paulo: Martin Claret, 2007.

CASTELO, P. A. História do ensino no Ceará. Fortaleza: Dep. de Imprensa Oficial, 1970.

FARIA FILHO, L. M. de. Processo de escolarização no Brasil. Algumas considerações e perspectivas de pesquisa. In: MENEZES, M. C. (Org.). Educação, memória e história. Possibilidades, leituras. Campinas, SP: Mercado das Letras, 2004.

FERRIÈRE, A. D. Pestalozzi y la nueva educación. Buenos Aires: T. G. de la Penitenciaría Nacional, 1928.

HOUSSAYE, J. (Org.) Quinze pedagogos. Textos selecionados. Petrópolis, RJ: De Petrus et alii, 2013.

HUBERT, R. História da pedagogia. São Paulo: Cia. Editora Nacional, 1957.

LARROYO, F. História geral da pedagogia. São Paulo: Mestre Jou, 1974.

LE GOFF, J. O Deus da Idade Média. Conversas com Jean-Luc Pouhier. Rio de Janeiro: Civilização Brasileira, 2010.

LUZURIAGA, L. História da educação e da pedagogia. São Paulo: Cia. Editora Nacional, 1976.

MARCILIO, M. L. História da escola em São Paulo e no Brasil. São Paulo: Inst. Fernand Braudel, 2005.

SAVIANI, D. História das ideias pedagógicas no Brasil. Campinas, SP: Autores Associados, 2008.

RIZZINI, I. Crianças e menores - do pátrio poder ao pátrio dever. Uma história da legislação para a infância no Brasil. In: RIZZINI, I; PILOTTI, F. (Org.). A arte de governar crianças. A história das políticas sociais, da legislação e da assistência à infância no Brasil. 2. ed. São Paulo: Cortez, 2009. p. 97-139

SOUSA, R. F. de. História da organização do trabalho escolar e do currículo no século XX. Ensino primário e secundário no Brasil. São Paulo: Cortez, 2008. 
VALDEMARIN, V.T. Estudando as lições das coisas. Análise dos fundamentos filosóficos do Método de Ensino Intuitivo. Campinas, SP: Associados, 2004.

VEIGA, C. G. História da educação. São Paulo: Ática, 2007.

Francisco Ari Andrade: Professor Associado DE da Faculdade de educação e do Programa de Pós-Graduação em Educação, da Linha de Pesquisa em História e Memória da Educação, da Universidade Federal do Ceará.

E-mail: andrade.ari@hotmail.com 